\title{
REDEFINING THE POTENTIAL ROLE OF CHARISMATIC LANGUAGE TEACHERS \\ IN CREATING SUPPORTIVE ACADEMIC ATMOSPHERE THROUGH STUDENTS' MOTIVATIONAL AROUSAL
}

\author{
Adi Suryani
}

\begin{abstract}
Charismatic language teachers have considerable potentials to nurture motivations in their students. They have personal magnetism which frequently they exhibit through their characters, communication, and how they develop relationship with their students. Charismatic teachers tend to be energetic, emphatic, warm, express confidence, love challenge, communicate vision, develop warm communication, put concern, trust, be inspiring and motivational. These characters allow them to be role model and inspire their motivation to their students. Their trusting behaviour also can lead to the creation of supportive classroom climate since supportive learning situation needs sense of autonomy. By having this sense of autonomy, students can voice their perspectives, beliefs and finally develop their autonomy self-regulation. By using their personal aura, charismatic language teachers can stimulate their students' inner motivation.
\end{abstract}

Keywords: Charismatic teachers, learning motivation, magnetism, support, concern, trust, inspiring, vision, learning climate, teacher-student relationship, communication, role model, personal aura, enthusiasm.

\section{Introduction}

This article aims to discuss how charismatic language educators are possible to induce conducive classroom and learning athmosphere. This contributive learning climate is expected to increase students motivation to learn. Many motivation scholars found that this inner drive can ignite students to reach maximum learning performance (Hanrahan, 1998). Charismatic educators can perform this capacity by exerting their enthusiasm, communication skill, vision, commitment and personal magnetic factors that they possess. Charismatic language educators can be different from non charismatic teachers. Positive and constructive charismatic educators can inspire many students to do what they ask their students to do. Moreover, charismatic educators can infuse their emotional aura. Emotion can be a virus which is contagious. Charismatic educators have big potential to influence/induce their emotional flow to their students. However, several dark sides of their magnetism, 
which may include total submission and unwilling obedience can potentially inhibit and conceal creativity and being too dependent on the charismatic figures.

Charismatic educators may able to rise students' motivation to learn by becoming role models, inspirational figures, even becoming the most favoured educators. This is very similar to charismatic leaders. Charismatic leaders can spell magic to their followers to execute their commands. This happens to many famous leaders. What makes Hitler a Germany's Führer? Or what makes Gandhi can move India people to fight for their freedom? There is something inside them which can move their people. Thus, it is possible that charismatic educators can be meaningful, leave impressive sense, and may affect their students' attitudes. Frequently, we cannot clearly defined a charisma. It is difficult to visually observe charisma, but we may feel it.

What is a charisma then? Weber $(1968$, p. 6) defines "charisma" as a divine gift that is possessed and endowed by a certain human. This gift makes the endowed human as having extraordinary quality, possessing superhuman attribution, and owning supernatural characteristics. There some people, not many people out there, have personal magnetism. They have inner appeal.

This paper aims to redefine the potential role of language charismatic educators in supporting students' motivation to learn. I argue that this supportive learning climate can be achieved by building harmonious relationships between teachers and students. This article covers the concept of students' motivation, teacher-student relationship, teachers' role, and language charismatic teaching by synthesizing and crossing the disciplines of educational leadership and management, classroom behaviour and learning. I start the discussion by redifining the concept of charisma, which I adopt from the perspective of charismatic leadership. Subsequently, I will relate this perspective of charismatic leadership with charismatic teaching, teaching behaviour and teacher-student relationship which potentially brings an impact on students' motivation. 


\section{Learning Charisma from Charismatic Leadership}

Teachership and leadership in some respect closely resembles. Teachers are responsible for their class and leaders are responsible for their organization. Teachers have to perform major roles as advisor, lecturer, evaluator, discussion leader and resource person (Grasha, 2002). Similarly, leaders have to perform roles in the areas of interpersonal, informasional, and decision making which encouage leaders to take care their followers, organizations, and becoming expertise (Lussier \& Achua, 2004). Charisma has been becoming important issue and long tradition in leadership area since charismatic leader has big fire which can burn their followers' energy, commitment, and loyalty, but not all leaders can be charismatic leaders (Klein \& House, 1995). Thus, it is important to learn from educational leadership discipline and relate some concept on that area with charisma in teaching.

From the perspective of educational leadership and management, charismatic leadership is one of several types of leadership which are frequently under debate. Some people believe that charisma is inborn, while others assume that charisma can be learnt. The latter perspective stimulates researchers, educators, and practitioners to explore charismatic personal qualities. They expect that charismatic personal can be grown, rehearsed, and transformed. Charismatic figures possess several distinguishing characteristics from non-charismatic ones. Dubrin and Dalglish (2003, pp. 67-70) note that charismatic leaders display several attributes, including visionary, communication mastery, ability to inspire trust, ability to heighten the sense of worth, highly energetic, emotional expresiveness, warmth and romanticize risk. Below are several striking characteristics in charismatic figures.

Communication mastery. Charismatic figures can communicate their messages in charming manner. This is because they demonstrate extraordinary communication skill. Moreover, different from non-charismatic leaders, charismatic leaders establish particular communication tactic. Lussier and Achua (2004, p. 350) assert that to command their followers, charismatic leaders use rhetorical skills, metaphors, analogies, and stories. Moreover, their communication tactics are

reinforced by communication trick. Roberts (2003, p. 23) exemplifies Hitler as frequently started his speech with deep, slowly and low intonation. He also 
frequently commenced his talk right after the applause of his audience is getting die down.

Ability to inspire trust. Follower's trust is also an important element in charismatic leadership. Charismatic leaders build their followers' trust through some ways. Charismatic leader can inspire trust on their followers by showing their expertise (Conger, 1989, p. 33). The charismatic leaders' followers are more likely trust their leaders when they can see that the leaders have a capacity to realize their vision. Differently, Lussier and Achua (2004, p. 351) contend that charismatic leaders establish their followers' trust through prioritizing the followers' needs over their own needs and building commitment to fulfill those needs. The followers of charismatic leaders' heavily trust their leaders. Therefore, they tend to comply with the leaders without questioning, showing total devotion, and possessing deep affection (House, 1997; House and Aditya, 1997, cited in Javidan and Waldman, 2003, p. 6).

Ability to raise self-importance and self-confidence on the followers. To generate self-confidence in their followers, the charismatic leaders themselves should have an enormous self-confidence. Bass (1990, p. 189) states that in any situation charismatic leaders have strong self-confidence, self-determination, and emotional expressiveness. To realize their vision, it is not sufficient for the charismatic leaders to have self-confidence within their own selves only. They need to build up their followers' self-confidence by generating their self-importance. Bandura (n.d., cited in House \& Howell, 1992, p. 99) states that those who have higher self-efficacy tend to do more action compared with those who have lower self-efficacy. Conger (1989, pp. 114-116) states that charismatic leaders use some tactics to inspire self-confidence, some of them are by making their followers feel important and special, giving personal rewards, and convincing them that they can finish their difficult task. Yukl (1994, p. 319) argues that charismatic leaders set a high expectation on their followers. In order to enable the followers to achieve their high expectation, the charismatic leaders express high self-confidence on their followers. 
Highly energetic. Charismatic leaders also have great enthusiasm and high level of energy to realize their visions. Dubrin and Dalgish (2003, p. 78) state that charismatic leaders have optimism, enthusiasm, and full of energy. Leaders will not be attributed as charismatic unless they can devote inexhaustible energy. As noted by Yukl (1994, p. 323) “ charismatic leaders appear so extraordinary, due to their strategic insight, strong conviction, self-confidence, unconventional behavior, and dynamic energy, that subordinates idolize these leaders and want to become like them."

Emotional expressiveness and warmth. Bass (1990, p. 190) notes that charismatic leaders can use non-verbal expressiveness to influence their followers. The charismatic leaders can use their gestures, facial expression, tone voice, smiles, and other non-verbal cues to appeal their followers.

Romanticize Risk. Dubrin and Dalgish (2003, p. 69) state that charismatic leaders like to face great risk. Thus, they tend to appear when the organization is in crises. Yukl (1990, p. 328) notes that charismatic leaders are likely to appear when the organization face a big problem. The unstable condition is likely more conducive for the emergence of charismatic leaders. Moreover, Cole $(2005$, p. 1) notes that charismatic leaders are demanded by state which will go to war. There are many charismatic leaders who are raised by war or military violence, for instance, Hitler, Mussolini, Saddam Husein, and Soekarno. Taking high risk is also one tactic used by charismatic leaders to attract their followers. As noted by Lussier and Achua (2004, p. 351) charismatic leaders get their followers admiration through facing high risk.

Vision. Having a clear vision is not the property of charismatic leaders only. Many other leaders also have a clear vision as the prerequisite to be effective leaders. As noted by Boston (1990, p. 87) that an effective leader should have a clear vision and know way to actualize his/her vision. However, charismatic leaders' vision can be distinguished from non-charismatic leaders in some aspects. Firstly, charismatic leaders have more ideal vision than other leaders. Conger (1989, p. 47) notes that leaders will be seen as more charismatic when they have more idealized vision. Secondly, that vision should challenge the current condition which is in 
crises and can provide solution for the existing situation shortcoming. As stated by Conger and Kanungo (1998, p. 1), the leaders will be more likely to be seen as charismatic leaders if their vision is more likely different from the present condition. The charismatic leaders can create an urgent need for a radical change and sell their vision as an alternative and the most reasonable solution. Conger (1989, pp. 30-31) notes that charismatic leaders can describe the current situation as not acceptable and demand a change.

From the above concept, it is apparent that charismatic leaders have capacity to ignite fire. Thus, in the following discussion, I intend to highlight charismatic teachers capacity to generate students' motivation through their personal characters. How charisma can be ignited is shown in the following figure.

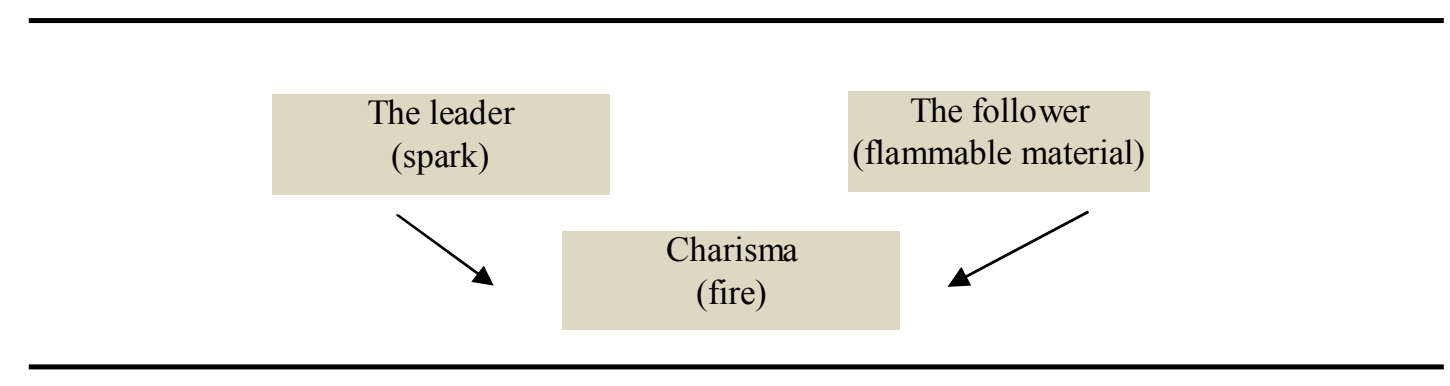

The anteceedent of charisma (charisma-conducive environment [oxygen])

(Klein \& House, 1995)

\section{Charismatic Teaching and Teacher Behaviour}

Charismatic leaders (leadership) can inform what happens in charismatic language teachers (teachership). There is strong relationship between leadership (especially educational leadership) and teacher (teachership). When we discuss issues on teachers' professional development, we will come to the discussion of teachers not only as teachers, but also as leaders (Steyn, 2004). When we examine teacher behaviour, we will also find leadership behaviour in teacher behaviour (Wei, Brok \& Zhou, 2009). Teacher behaviour can be related to leader behaviour (Dunham, 1965; Swanson, 1974; Dawson, Messe \& Phillips, 1972; LahatMandelbaum \& Kipnis, 1973; Norr \& Crittenden, 1975, cited in Archer, 1994).

Similar to leaders who perform various imporatant roles, teachers also have diverse roles. Grasha (2002) identifies several roles of teachers, including: active 
designer, active listener, actor/director, assigner, case designer/organizer, coach, consultant, content expert, coordinator, discussion facilitator, formative evaluator, grader, lecturer, material designer/organizer, mini-lecturer, negotiation, nondirective facilitator, prescriptive advisor, process observer, questioner, resource person and role model. Among teachers' various roles, charismatic teachers tend to focus on inspiring and motivating students' vision (Archer, 1994). This can be done by becoming a role model for their students. Charismatic leadership concept shows that charismatic leaders are energetic, full of enthusiasm, warm, and have strong belief, values, and vision. Charismatic leaders have high self-confidence, strongly convict to their ideals and beliefs, and are able to influence others (House, 1977, cited in Archer, 1994). This indicates that charismatic teachers also have influencing power. Their capacity or power to influence others can be a great way for them to be able to inspire or motivate students more than other teachers. Moreover, they can empower their students by generating students' self efficacy.

\begin{tabular}{|c|c|c|c|}
\hline \multicolumn{2}{|c|}{ Intellectual excitement } & \multicolumn{2}{|c|}{ Interpersonal Rapport } \\
\hline $\begin{array}{l}\text { enthusiastic } \\
\text { knowleadgeable }\end{array}$ & $\begin{array}{l}\text { exciting } \\
\text { engaging }\end{array}$ & $\begin{array}{l}\text { Interpersonal } \\
\text { concern: }\end{array}$ & $\begin{array}{l}\text { Effective } \\
\text { motivation: }\end{array}$ \\
\hline $\begin{array}{l}\text { inspiring } \\
\text { humorous } \\
\text { interesting } \\
\text { clear } \\
\text { organized } \\
\text { creative }\end{array}$ & $\begin{array}{l}\text { prepared } \\
\text { energetic } \\
\text { fun } \\
\text { stimulating } \\
\text { eloquent } \\
\text { communicative }\end{array}$ & $\begin{array}{l}\text { concerned } \\
\text { caring } \\
\text { available } \\
\text { friendly } \\
\text { accessible } \\
\text { approachable }\end{array}$ & $\begin{array}{l}\text { helpful } \\
\text { encouraging } \\
\text { challenging } \\
\text { fun } \\
\text { demanding } \\
\text { patient } \\
\text { motivating }\end{array}$ \\
\hline
\end{tabular}

A classification of descriptors of classroom behaviour (Lowman, 1994, cited in Grasha, 2002)

Charismatic language teachers can affect their students by using their intellectual excitement and interpersonal rapport. Grasha (2002) puts the details of intellectual excitement and interpersonal rapport in the above table. There are several aspects from the table above which are relevant to charismatic leadership. This also implies that it is possible that charismatic teachers develop particular behaviour, including being enthusiastic, inspiring, clear, energetic, stimulating, communicative, concerned, caring, encouraging, challenging and motivating. 
Similarly, Archer (1994) mentions that there are several characters of charismatic teachers: enthusiastic, caring, concern, energetic, personal empathy, personal intensity, intellectual challenge, trust and commitment. Ideal teachers are those who have leadership character, helpful and friendly and to some extent, provide sense of flexibility to their students (Wei, Brok \& Zhou, 2009). Charismatic teachers have strong character and role of becoming transmitter of inspiration (Archer, 1994) or "creator of a motivating vision" (Tichy \& Devanna, 1986, p. 29). This vision will help students to have goals, be committed to goals, focus, devote high energy, compel courage (Senge, 2006). Thus, charismatic teachers are very significant in laying students' foundation of learning.

By burning (igniting) fire to their students, charismatic teachers can potentially lead their students to be aware of the meaning of learning process, becoming hard working, and being longlife learner. This is as mentioned by Ames (1990) as follows:

\footnotetext{
"...When we talk about motivation as an outcome, we are concerned with students" "motivation to learn." If we place a value on developing a motivation to learn in students, we are concerned wih whether students initiate learning activities and maintain an involvement in learning as well as a commitment to the process of learning. Effective schools and effective teachers are those who develop goals, beliefs, and attitudes in students that will sustain a long term involevement and that will contribute to the quality involvement in learning.

If we evaluate our schools and classroom strictly by how much students achieve, we can easily lose sight of these other educational goals and values. We not only want students to achive. We want them to value the process of learning and the improvement of their skills, we want them to willingly put forth the necessary effort to develop a long term commitment to learning. It is in this sense that motivation is an outcome of education..."(p. 140).
}

It shows that generating motivation is the genuine goal of our education. Charismatic teachers can potentially boost students' motivation to learn. If we refer to the model of anteceedent of charisma (charisma conducive environment [oxygen]) by Klein and House (1995) above, it implies that charismatic teachers can use their personal magnetism and relationship approach to potentially influence their students. This also means that charismatic teachers can develop both their social and emotional competence. They use their social competence especially when they build relationship and communicate with their students. They exhibit their emotional 
capacity when they have to regulate their inner states. Both of those competencies are closely related and affect each other. Socially and emotionally competent teachers possess strong self awareness, social awareness, responsible for their decision making, high self management, and relationship management (Zins, Weissberg, Wang \& Walberg, 2004, cited in Jennings \& Greenberg, 2009, p. 494). Thus, charismatic teachers are not only spreading their aura or charm, but they also developing and maintaining their social and emotional states.

Charismatic characters can be learnt. Charismatic teachers are not born, but they are made. They are nurtured instead of being natured (Johnson, Vernon, McCarthy, Molson, Harris, \& Jang, 1998). This is implied from some charismatic leadership concept. Charisma is not personality traits (Conger \& Kanungo, 1987, cited in Archer, 1994). This indicates that charismatic characters can be formed. Moreover, charismatic behaviour can be measured, can be identified since what makes teachers charismatic or not is depending on their students' perception (Archer, 1994; Ames, 1992, cited in Archer, 1994). This entails that the power of charismatic teachers can be learnt. One of several powerful characteristics of charismatic teachers is motivating arousal. There are several strategies for generating motivation. Keller (1987) proposes several approaches for strengthening motivation.

\begin{tabular}{|c|c|c|}
\hline \multicolumn{2}{|c|}{ Major categories \& Definitions } & Major Process Questions \\
\hline $\begin{array}{l}\text { Attention } \\
\text { Relevance } \\
\text { Confidence } \\
\text { Satisfaction }\end{array}$ & $\begin{array}{l}\text { Capturing the interest of learners; } \\
\text { Stimulating the curiosity to learn } \\
\text { Meeting the personal needs/goals } \\
\text { of the learner to affect a positive } \\
\text { attitude. } \\
\text { Helping the learners believe/feel } \\
\text { that they will succeed and control } \\
\text { their success. } \\
\text { Reinforcing accomplishment } \\
\text { with rewards (internal and } \\
\text { external) }\end{array}$ & $\begin{array}{l}\text { "How is this learning valuable } \\
\text { and stimulating to my students?" } \\
\text { "How can I (via instruction) help } \\
\text { student succeed and allow them } \\
\text { to control their outcomes?" }\end{array}$ \\
\hline
\end{tabular}

The ARCS Model of motivation (Keller, 1987, p. 2) 
More specifically, Keller (1987) puts in more details each component of ARCS model into subcategories, process questions and main supporting strategies.

\section{Components of attention}

\begin{tabular}{|l|l|l|}
\hline \multicolumn{1}{|c|}{$\begin{array}{c}\text { Sub } \\
\text { categories }\end{array}$} & \multicolumn{1}{c|}{$\begin{array}{c}\text { Process } \\
\text { Questions }\end{array}$} & \multicolumn{1}{c|}{ Main Supporting Strategies } \\
\hline $\begin{array}{l}\text { Perceptual } \\
\text { Arousal }\end{array}$ & $\begin{array}{l}\text { What can I do to capture their } \\
\text { interest? }\end{array}$ & $\begin{array}{l}\text { Create curiosity, wonderment by using novel approaches, } \\
\text { injecting personal and/or emotional material }\end{array}$ \\
\hline $\begin{array}{l}\text { Inquiry } \\
\text { Arousal }\end{array}$ & $\begin{array}{l}\text { How can I stimulate an attitude } \\
\text { of inquiry? }\end{array}$ & $\begin{array}{l}\text { Increase curiosity by asking questions, creating paradoxes, } \\
\text { generating inquiry and nurturing thinking challenges }\end{array}$ \\
\hline Variability & $\begin{array}{l}\text { How can I maintain their } \\
\text { attention? }\end{array}$ & $\begin{array}{l}\text { Sustain interest with variations in presentation style, concrete analogies, } \\
\text { human interest examples, and unexpected events }\end{array}$ \\
\hline
\end{tabular}

Components of relevance

\begin{tabular}{|l|l|l|}
\hline \multicolumn{1}{|c|}{$\begin{array}{c}\text { Sub } \\
\text { categories }\end{array}$} & \multicolumn{1}{c|}{$\begin{array}{c}\text { Process } \\
\text { Questions }\end{array}$} & \multicolumn{1}{c|}{ Main Supporting Strategies } \\
\hline $\begin{array}{l}\text { Goal } \\
\text { orientation }\end{array}$ & $\begin{array}{l}\text { How can I best meet my } \\
\text { learners' needs? (Do I know } \\
\text { their needs?) }\end{array}$ & $\begin{array}{l}\text { Provide statements or examples of the utility of the instruction, } \\
\text { and either present goals or have learners define them. }\end{array}$ \\
\hline $\begin{array}{l}\text { Motive } \\
\text { matching }\end{array}$ & $\begin{array}{l}\text { How and when can I provide } \\
\text { my learners with apropriate } \\
\text { choices, responsibilities, and } \\
\text { influences? }\end{array}$ & $\begin{array}{l}\text { Make instruction responsive to learner motives and values by providing } \\
\text { personal achievement opportunities, cooperative activities, leadership } \\
\text { responsibilities and positive role models. }\end{array}$ \\
\hline Familiarity & $\begin{array}{l}\text { How can I tie the instruction to } \\
\text { the learners' perspectives? }\end{array}$ & $\begin{array}{l}\text { Make the materials and concepts familiar by providing concrete examples } \\
\text { and analogies related to the learners' work. }\end{array}$ \\
\hline
\end{tabular}

Components of confidence

\begin{tabular}{|l|l|l|}
\hline \multicolumn{1}{|c|}{$\begin{array}{c}\text { Sub } \\
\text { categories }\end{array}$} & \multicolumn{1}{c|}{$\begin{array}{c}\text { Process } \\
\text { Questions }\end{array}$} & \multicolumn{1}{c|}{ Main Supporting Strategies } \\
\hline $\begin{array}{l}\text { Learning } \\
\text { requirements }\end{array}$ & $\begin{array}{l}\text { How can I assist in building a } \\
\text { positive expectation for } \\
\text { success? }\end{array}$ & $\begin{array}{l}\text { Establishing trust and positive expectations by explaining } \\
\text { the requirements for success and the evaluative criteria }\end{array}$ \\
\hline $\begin{array}{l}\text { Success } \\
\text { opportunities }\end{array}$ & $\begin{array}{l}\text { How will the learning } \\
\text { experience support or enhance } \\
\text { the students' belief in their } \\
\text { competence }\end{array}$ & $\begin{array}{l}\text { Increase belief in competence by providing many, } \\
\text { varied and challenging experiences which increase learning success }\end{array}$ \\
\hline $\begin{array}{l}\text { Personal } \\
\text { control }\end{array}$ & $\begin{array}{l}\text { How will the learners clearly } \\
\text { know their success is based } \\
\text { upon their efforts and abilities? }\end{array}$ & $\begin{array}{l}\text { Use techniques that offer personal control (whenever possible), } \\
\text { and provide feedback that attributes success to personal effort. }\end{array}$ \\
\hline
\end{tabular}

\section{Components of satisfaction}

\begin{tabular}{|c|c|c|}
\hline $\begin{array}{l}\text { Sub } \\
\text { categories }\end{array}$ & $\begin{array}{l}\text { Process } \\
\text { Questions }\end{array}$ & Main Supporting Strategies \\
\hline $\begin{array}{l}\text { Natural } \\
\text { consequences }\end{array}$ & $\begin{array}{l}\text { How can I provide meaningful } \\
\text { opportunities for learners to use } \\
\text { their newly acquired } \\
\text { knowledge/skill? }\end{array}$ & $\begin{array}{l}\text { Provide problems, simulations, or work samples } \\
\text { that allow students to see how they can now solve "real world" problems. }\end{array}$ \\
\hline $\begin{array}{l}\text { Positive } \\
\text { consequences }\end{array}$ & $\begin{array}{l}\text { What will provide } \\
\text { reinforcement to the learners' } \\
\text { successes? }\end{array}$ & Use verbal praise, real or symbolic rewards and incentives \\
\hline Equity & $\begin{array}{l}\text { How can I assisst the students } \\
\text { in anchoring a positive feeling } \\
\text { about their accomplishments? }\end{array}$ & $\begin{array}{l}\text { Make performance requirements consistent with stated expectations, } \\
\text { and provide consistent measurement standards for all learner's tasks and } \\
\text { accomplishments. }\end{array}$ \\
\hline
\end{tabular}

The details of the components of ARCS Model of motivation (Keller, 1987, p. 2) 


\section{Social Learning in Charismatic Teacher and Student Relationship}

Charismatic teachers do not have personal attributes only, but they also develop certain teacher-student relationship. The model of anteceedent of charisma by Klein and House (1995), on page 5, shows that what makes a charisma is the mixture of personal magnetism and conditions of the followers. This means that it is possible that charismatic teachers need certain approach to relate to their students. A teacher is considered a charismatic teacher by his/her students because his/her students feel that the teacher has relational attributes (Archer, 1994). Students tend to love their teachers with high enthusiasm and interact in an engaging manner with their students (Archer, 1994). Charismatic teachers also build trusting, motivating through challenge, empathetic and excited relationship with their students (Archer, 1994). Thus, charismatic teachers tend to develop emotional attachment with their students.

Through interaction, charismatic teachers become role teachers. Students tend to admire their charismatic teachers and through social process and identification. They uncounciously learn to identify themselves to their charismatic teachers. This means that they learn to be look like (to become just like) their charismatic teachers, they are eager to meet the requirement of their favourite teachers, even they are committed to their teachers. In this situation, the behaviour of charismatic teachers can be stimulus for their students to perform social learning. In a social learning process, learners can acquire new knowledge by engaging in direct experience or observing the behaviour of others (Bandura, 1971).

In this social learning process, students perform observational learning. In this learning operation, they go through gradual operations: attentional, retention, and motoric representative processes (Bandura, 1971). During the attentional process, learners try to recognize and select prominent features of their models' behaviour, in retention process, learners are remembering (memorizing) the modelled behaviour, and during the motoric representative operation, learners start collecting together the modelled pattern and exhibit new behaviour based on the modelled behaviour (Bandura, 1971). This implies that when students build strong interaction with their charismatic teachers, they are selecting their charismatic 
teachers' behaviour that makes them impressed; they remember that behaviour; and they relate those behaviours and adopt those behaviours. This indicates that in adopting the modelled behaviour, learners may involve their cognition in selecting and remembering the modelled behaviour.

The relationship between charismatic teachers and their students can also be characterized by rewarding interaction. This means that charismatic teachers are competent teachers in reinforcing through rewarding. Their reinforcing behaviour can be detected through their convincing behaviour, when they help their students to believe that they can be success, as indicated in the ACRS model of motivation, proposed by Keller (1987). This rewarding behaviour is one of several forms of reinforcement. Through this rewarding, teachers can actually motivate their students (Bandura, 1971).

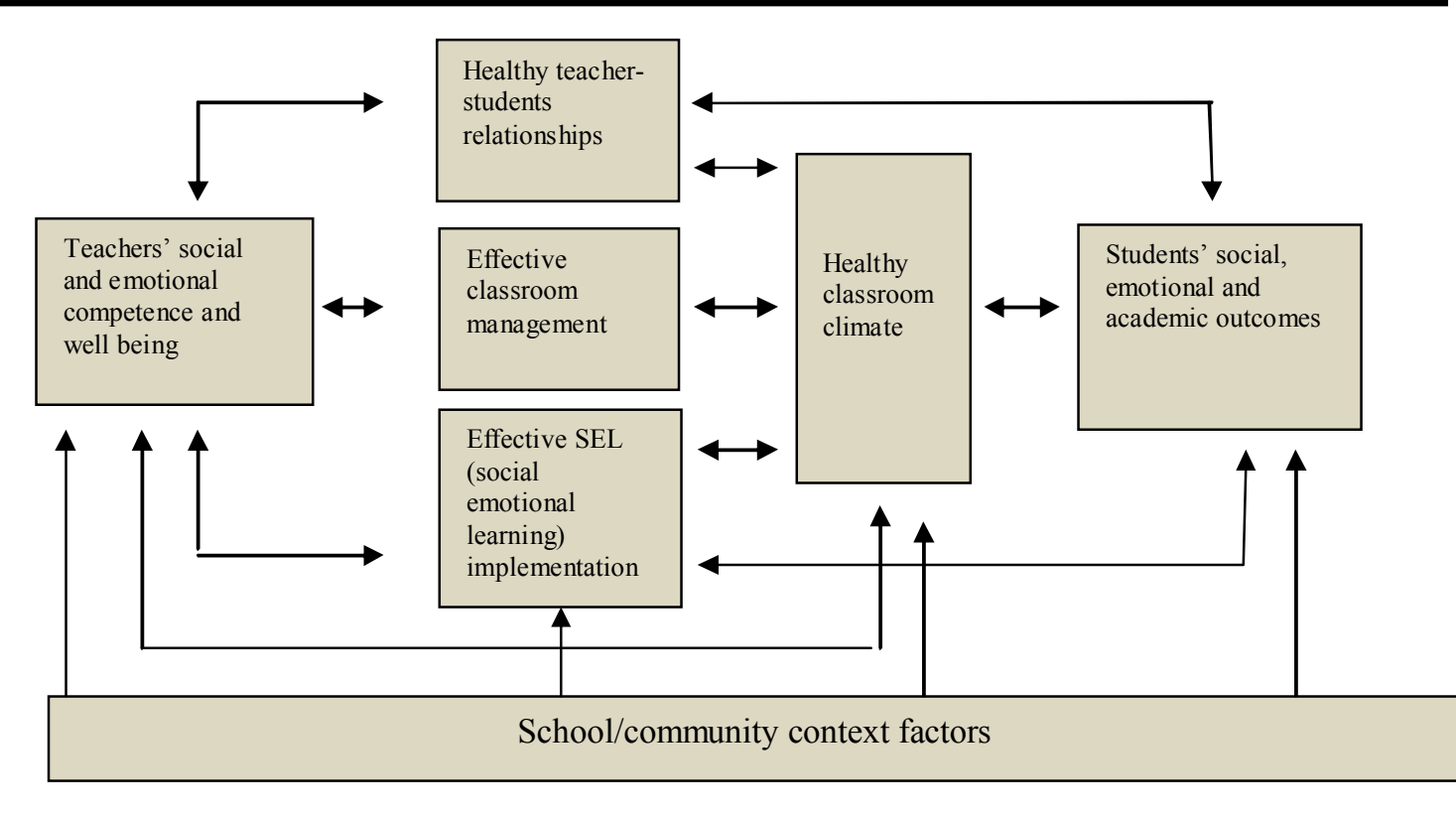

The prosocial classroom: A model of teacher social and emotional competence classroom and student outcomes (Jennings \& Greenberg, 2008, p. 494)

The equal balance between charismatic teachers' inner states and outer states or personal characters and relational attributes can contribute to the creation and development of their healthy classroom. Teachers who always try to show 
exemplary behaviour, exhibit trusting, motivating, inspiring, emphathetic behaviour and deep care can inspire their students to develop healthy social and emotional states. This is as proposed by Jennings and Greenberg (2008) and presented in the figure of prosocial classroom: A model of teacher social and emotional competence classroom and student outcomes).

\section{Students' Motivation in Second Language Classroom}

The concept of charismatic leaders and chraismatic teachers indicate that charismatic individuals tend to develop caring, warm, suportive, trusting, inspiring, motivating, and empathetic behaviour. Several educational theoriests argue that teachers behaviours have strong impact on students' motivation. Charismatic teachers' ways of communication can directly affect students' positive feeling. This feeling can be the foundation of intrinsic motivation. Many scholars believe that instrinsic motivation is more powerful than extrinsic motivation (Dörnyei, n.d.; Assor, Kaplan \& Roth, 2002; Deci, Vallerand, Pelletier \& Ryan, 1991; Noels, Clément \& Pelletier, 1999;Reeve, Elizabeth \& Cai, 1999; Lumsden, 1994). This feeling is stronger than external rewards, for example getting higher grade or academic recognition from peers or teachers in motivating students. It is significant for growing and developing students' self determination. Self determined students tend to learn things happily, voluntarily based on their self satisfaction, enjoyment, and challenge instead of external rewards/replies (Noels, Clément, Pelletier, 1999). Self determination can also increase students' interest and self confidence (Deci, Vallerand, Pelletier \& Ryan, 1991). This entails that how teachers' behave will influence students' motivation. This is supported by several scholars, including Reeve, Elizabeth \& Cai (1999), Noels, Clément \& Pelletier (1999), Brophy and Good (1984), Christophel (1990).

The motivating, trusting, and supporting behaviours of charismatic teachers can stimulate their students' independency which may affect their learning outcome. This is as described in the following figure. 


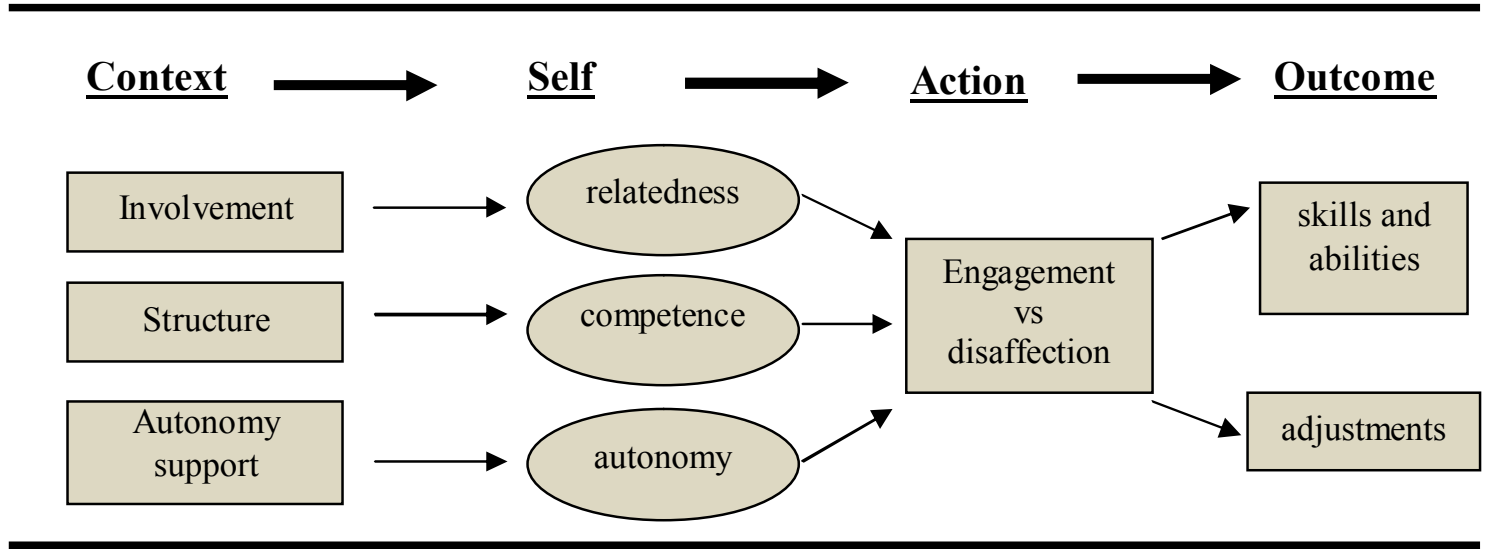

A motivational model of the effects of children's psychological needs on their engagement (J.P. Connell \& J., G. Wellborn, 1991, in M., R. Gunnar \& L., A. Sroufe, 1991, cited in Skinner \& Belmont, 1993).

Similar to the above context of motivation, motivation in second language learning also requires the presence of supportive teachers. This is because motivation in second language context is not closely related to how passionate students on language subject matter only, but also how learning situation and classroom environment can sustain and increase their enthusiasm to learn language. There are two dimensions of motivation in second language learning: motivation to take any opportunity to learn language and motivation in language learning situation (Gardner, 2007). This is relevant to Dornyei's (1994) concept of motivation in language learning who argues that there are three elements of motivation in second language learning: motivation relating to the content of subject, relating to teacher and group. This implies that language teachers' behaviour tend to affect their students' behaviour. Motivation in learning second language can be affected by positive behaviour towards second language (Clement, Dornyei \& Noels, 1994). This is also supported by Gardner (2007) who argues that language achivement and use are dependent on cultural context including students' individual attitudes, beliefs and personality, and educational context covering the learning system, quality of program, interest, enthusiasm, teachers, material, curriculum, and classroom athmosphere. Teachers and classroom situation are part of the educational context. Teachers play significant role in creating motivating classroom climate. When the teachers get angry very easily, it is possible that the classroom situation will be 
uncomfortable. Emotion can affect other people in workplace (Hochschild, 2003; Ashkanasy \& Daus, 2001). Interesting and fun classroom can encourage students to engage in learning (Boekaerts, 2010). This implies that supportive classroom can motivate students.

\begin{tabular}{|c|c|}
\hline \multicolumn{2}{|c|}{$\begin{array}{l}\text { Nurture Inner Motivational Resources. } \\
\text { To initiate students' participation, }\end{array}$} \\
\hline $\begin{array}{l}\text { Nurture inner resources } \\
\text { - Interest } \\
\text { - } \text { Preferences } \\
\text { - Choice making } \\
\text { - } \text { Curiosity } \\
\text { Sense of challange }\end{array}$ & $\begin{array}{l}\text { Rely on extrinsic motivators: } \\
\text { - Incentives } \\
\text { - Consequences } \\
\text { - Directives } \\
\text { - Deadlines } \\
\text { - Assignments }\end{array}$ \\
\hline $\begin{array}{l}\text { What autonomy teachers do: } \\
\text { To solve the motivational problem of initiating students' } \\
\text { activity, autonomy-supportive teachers find ways to } \\
\text { incorporate students' interest, preferences, choices, } \\
\text { curiosity, or sense of challenge into the lesson }\end{array}$ & $\begin{array}{l}\text { What controlling teachers do: } \\
\text { To solve the motivational problem of initiating students' } \\
\text { activity, controlling teachers neglect students' inner } \\
\text { resources and instead try to manufacture extrinsic } \\
\text { motivation by offering incentives, consequences, } \\
\text { directives, deadlines, or assignments. }\end{array}$ \\
\hline
\end{tabular}

One computer screen from the study-specific website to communicate how teachers might support students' autonomy during instruction (Reeve, Jang, Carrell, Jeon \& Barch, 2004). e they have personal characters relevant to the essential ingredients of motivating classroom. Charismatic teachers have potential capacity to exhibit their motivating behaviours through their behaviour as role models and through their communication (Midgley, Feldlaufer \& Eccles, 1988, p. 555). They have this big potential since they have their personal magnetism (aura) which can easily attract their students to see and adopt their styles, beliefs, and values. To nurture students' motivation, they can adopt certain strategies. Those strategies are as presented in the above figure. It shows that providing students sense of autonomy can generate their internal motivation. This sense of autonomy is closely related to the trusting behaviour. When teachers trust their students. They tend to facilitate their learning instead of controlling, they can facilitate their students to have their own perspective, thinking and feeling, and grow autonomous self regulation (Reeve, 2009). This trusting behaviour is one of several characteristics of charismatic teachers. 


\section{Conclusion}

Charismatic language teachers have high potential to create motivating classroom. They have personal magnetism. Charismatic teachers tend to communicate warmly, love challenge, inspire vision, trust, put high energy, be enthusiastic, be emphatic, inspire self confidence, caring, encouraging and exciting. They also develop caring, motivating and trusting relationship. By having those characters and relationships, charismatic teachers have potential role and capacity to nurture students' inner motivation. They can inspire their students' motivation by performing charismatic behaviours and develop warm communication. By trusting, caring and emphatizing their students, they can develop autonomy-supportive classroom learning climate. It is indicated this type of classroom situation can contribute significantly to autonomous self-regulation.

\section{Reference List}

Ames, C., A. (1990). Motivation: What teachers need to know. Teachers' College Record, vol. 91, no. 3, Columbia University.

Archer, A., C. (1994). The measurement of charismatic teaching in college classroom. A paper presented at the Annual Meeting of the American Education Research Association.

Ashkanasy, N., M. \& Daus, C. (2001). Emotion in the workplace: The new challenge for managers. A paper submitted to the Academy of Management Executive, 16, 1, 76-86.

Assor, A., Kaplan, H., Roth, G. (2002). Choice is good, but relevance is excellent: Autonomy-enhancing and suppressing teacher behaviours predicting students' engagement in schoolwork. British Journal of Educational Psychology, 72, 261278.

Bandura, A. (1971). Social learning theory. New York: General Learning Press.

Bass, B.M. (1990). Handbook of leadership. Theory, research \& managerial applications. $3^{\text {rd }}$ Edn. New York: The Free Press.

Boekaerts, M. (2010). The crucial role of motivation and emotion in classroom learning. In H. Dumont, D., Instance \& F. Benadives (2010). The Nature of Learning. Using Research to Inspire Practice. Centre for Educational Research. 
Boston, J.A. (1990). Global education. From thought to action (Tye, K.A., Ed.). Alexandria: Association for Supervision and Curriculum Development.

Brophy, J. \& Good, T., L. (1984). Teacher behaviour and student achievement. Occasional Paper, no. 73, 3-174.

Christophel, D., M. (1990). The relationships among teacher immediacy behaviours, student motivation and communication education. Communication Education, 39, 323-340.

Clement, R., Dornyei, Z., \& Noels, K., A. (1994). Motivation, self confidence and group cohesion in the foreign language classroom. Language Learning, 44, 3, 417-448.

Cole, J.M. (2005). The Kurtz factor: Charismatic Leadership in war and terrorism. Paper presented to the Conference of Defense Associations Institute Graduate Symposium. Kingston, Ontario, 28-29 October.

Conger J. \& Kanungo, R. (1998). Charismatic leadership in organizations. National College for School Leadership.

Conger, J.A. (1989). The charismatic leader. Behind the mystique of exceptional leadership. California: Jossey-Bass Publishers.

Deci, E., L., Vallerand, R., J., Pelletier, L., G. \& Ryan, R., M. (1991). Motivation and education: The self-determination perspective. Educational Psychologist, $26,3 \& 4,325-346$.

Dornyei, Z. (1994). Motivation and motivating in the foreign language classroom. The Modern Language Journal, 78, 3, 272-284.

Dörnyei, Z. (n.d.). Attitudes, orientations, and motivations in language learning: Advances in theory, reserach, and applications. School of English Studies, University of Notthingham.

Dubrin, A.J. \& Dalgish, C. (2003). Leadership. An Australasian focus. Melbourne: John Wiley \& Sons Australia, Ltd.

Gardner, R., C. (2007). Motivation and second language acquisition. Porta Linguarum, pp. 9-20.

Grasha, A., F. (2002). Teaching with style. A practical guide to enhancing learning by understanding teaching and learning styles. CA: Alliance Publisher, online version, retreived from www.googlescholar.com, on Januray 24, 2014. 
Hanrahan, M. (1998). The effect of learning environment factors on students' motivation and learning. International Journal of Science Education, 20 (6), 737-753. Retrieved from www.googlescholar.com, on September 20, 2014.

Hochschild, A., R. (2003). The managed heart: Commercialization of human feeling. California: University of California Press.

Javidan, M. \& Waldman, D.A. (2003). Exploring charismatic leadership in the public sector: Measurement and consequences. Public Administration Review, 63 (2), 229-243.

Jennings, P., A. \& Greenberg, M., T. (2009). The prosocial classroom : Teacher social and emotional competence in relation to student and classroom outcomes. Review of Educational Research, 79, 1, 491-525.

Johnson, A., M., Vernon, J., M., McCarthy, J., M., Molson, M., Harris, J., A. \& Jang, K., L. (1998). Nature vs nurture: Are leaders born or made? A behaviour genetic investigation of leadership style. Twin Research, 1, 216-223.

Keller, J., M. (1987). Strategies for stimulating the motivation to learn. Performance \& Instruction, 1-7.

Klein, K., J. \& House, R., J. (1995). On fire: Charismatic leadership and levels of analysis. Leadership Quarterly, 6, 2, 183-198. Retreived from www.googlescholar.com, on September 18, 2014.

Lumsden, L., S. (1994). Student motivation to learn. ERIC Digest, no. 92, pp. 1-7.

Lussier, R.N. \& Achua, C.F. (2004). Leadership: Theory, application, skill development. Eagan, Minnesota: Thompson, South Western.

Midgley, C., Feldlaufer, H. \& Eccles, J., S. (1988). The transition to junior high school: Beliefs of pre- and posttransition teacher. Journal of Youth and Adolescence, 17, 6, 543-562.

Noels, K., A., Clément, R. \& Pelletier, L., G. (1999). Perceptions of teachers' communicative style and students' intrinsic and extrinsic motivation. The Modern Language Journal, 8, 3, 23-34.

Reeve, J. (2009). Why teachers adopt a controlling motivating style toward students and how they can become autonomy supportive. Educational Psychologist, 44, $3,159-175$.

Roberts, A. (2003). Hitler \& Churchill. Secrets of leadership. London: Weidenfield \& Nicolson. 
Reeve, J., Jang, H., Carrell, D., Jeon, S. \& Barch, J. (2004). Enhancing students' engagement by increasing teachers' autonomy support. Motivation and Education, 28, 2, 147-169.

Reeve, J., Elizabeth, B. \& cai, Y. (1999). Autonomy-supportive teachers: How they teach and motivate students. Journals of Educational Psychology, 91, 3, 537548 .

Senge, P., M. (2006). The fifth discipline. The art \& practice of the learning organization, London: Random House Business Book.

Skinner, E., A. \& Belmont, M., J. 91993). Motivation in the classroom: Reciprocal effects of teacher behaviour and student engagement across the school year. Journal of Educational Psychology, 85, 4, 571-581.

Steyn, G., M. (2004). How do professional develop? Lesson for the effective implementation of the South African skills development act. South African Journal of Education, 24, 3, 217-224.

Weber, M. (1968). On charisma and institution building. Chicago: The University of Chicago Press.

Wei, M., Brok, P. \& Zhou, Y. (2009). Teacher interpersonal behaviour and student achievement in English as a foreign language classroom in China. Learning Environments Research.

Yukl, G. (1994). Leadership in organizations. $3^{\text {rd }}$ Edn. New Jersey: Prentice-Hall, Inc. 